\title{
Likuiditas Bank Umum Syariah di Indonesia: Analisis Tingkat Kecukupan Modal, Tingkat Pembiayaan Bermasalah dan Inflasi
}

\author{
Leni Nuraeni', Heraeni Tanuatmodjo 2 , dan Aneu Cakhyaneu ${ }^{3}$ \\ leninuraenio3@gmail.com
}

1,2,3 Ilmu Ekonomi dan Keuangan Islam, Universitas Pendidikan Indonesia

KEYWORD

Tingkat Kecukupan

Modal,

Tingkat Pembiayaan

Bermasalah, Inflasi dan Tingkat

Likuiditas

\section{ABSTRACT}

Likuiditas Bank Umum Syariah selama enam tahun terakhir mengalami fluktuasi dan meningkat. Semakin tinggi tingkat likuiditas maka samakin tinggi keuntungan yang diperoleh bank, namun ketika tingkat likuiditas tinggi maka bank akan kesulitan dalam memperoleh cadangan kas karena bank banyak melakukan pembiayaan. Maka dari itu, likuiditas bank harus berada di tengahtengah artinya tidak terlalu kecil dan tidak terlalu besar. Penelitian ini bertujuan untuk melihat gambaran serta pengaruh tingkat kecukupan modal, tingkat pembiayaan bermasalah dan inflasi terhadap tingkat likuiditas Bank Umum Syariah di Indonesia periode 2014-2019. Metode penelitian yang digunakan dalam penelitian ini adalah metode deskriptif kuantitatif. Populasi pada penelitian ini adalah Bank Umum Syariah yang terdaftar di Otoritas Jasa Keuangan (OJK). Sampel penelitian berjumlah 12 Bank Umum Syariah yang diperoleh berdasarkan purposive sampling dengan periode penelitian selama enam tahun penelitian sehingga data observasi berjumlah 72. Data yang digunakan adala data sekunder. Teknik analisis statistik yang digunakan dalam penelitian ini adalah analisis regresi data panel dengan menggunakan Eviews 9. Variable dependen dalam penelitian ini adalah tingkat likuiditas dan variable independent dalam penelitian ini adalah tingkat kecukupan modal, tingkat pembiayaan bermasalah dan inflasi. Hasil penelitian ini menunjukan bahwa tingkat kecukupan modal berpengaruh terhadap tingkat likuiditas, tingkat pembiayaan bermasalah tidak berpengaruh terhadap tingkat likuiditas dan inflasi tidak berpengaruh terhadap tingkat likuiditas. 


\section{Introduction}

Likuiditas dari tahun ke tahun menjadi masalah bagi Bank Umum Syariah (BUS). Likuiditas merupakan hal yang sangat penting bagi bank syariah dalam menjalankan aktivitas bisnisnya baik untuk memenuhi kebutuhan segera, memenuhi kebutuhan nasabah terhadap pembiayaan dan memberikan kemudahan dalam meraih kesempatan investasi yang menarik dan menguntungkan. Likuiditas merupakan salah satu indikator pengukur tingkat kesehatan bank terhadap kinerja keuangannya. Tingkat likuiditas di bank syariah dapat menggunakan beberapa indikator di antaranya Quick Ratio, Investing Policy Ratio, Cash Ratio dan Financing to Deposit Ratio. Dalam hal ini, peneliti menggunakan Financing to Deposit Ratio (FDR) sebagai indikator dari tingkat likuiditas. Berdasarkan FDR, likuiditas di bank syariah menurun. Otoritas Jasa Keuangan (OJK) mencatat perkembangan tingkat likuiditas Bank Umum Syariah yang dapat dilihat pada gambar di bawah ini:

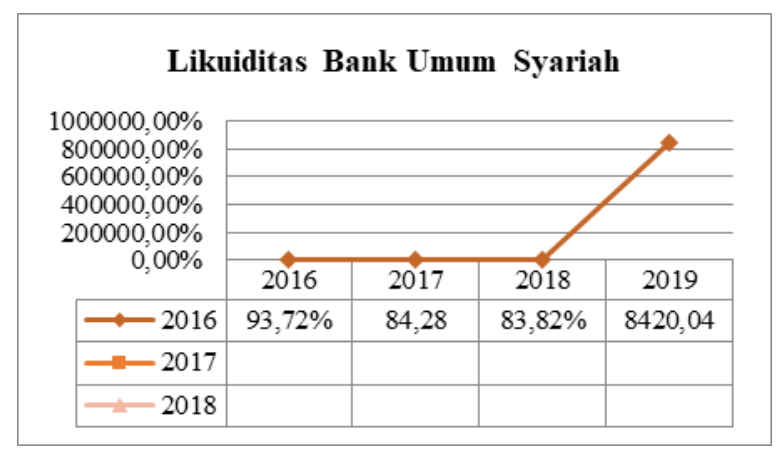

Sumber: Laporan Keuangan Bank Umum Syariah 2014-2018

\section{Gambar 1. 1 Perkembangan Tingkat Likuiditas Bank Umum Syariah}

Gambar 1.1 di atas, dapat dilihat bahwa tingkat likuiditas BUS mengalami penurunan dari tahun 2016 ke tahun 2017 hingga tahun 2018, sedangkan pada tahun 2019 mengalami peningkatan (Laporan Keuangan Bank Umum Syariah, 2014-2019). Penurunan ini menunjukkan bahwa bank syariah tidak dapat memaksimalkan dalam melakukan pembiayaan ke masyarakat maupun ke sektor riil atau bank syariah tidak dapat mengefektifkan dana yang dihimpunnya. Selain itu, penurunan tingkat likuiditas akan menyebabkan turunnya kepercayaan masyarakat terhadap BUS jika likuiditas yang rendah tidak segera di atasi sehingga akan mengganggu tingkat profitabilitas yang diperoleh bank tersebut. Peningkatan likuiditas pada tahun 2019 telah melebihi kriteria likuiditas Bank Umum Syariah sehingga bank akan kesulitan memperoleh cadangan kas karena uang banyak digulirkan untuk pembiayaan. Oleh karena itu likuiditas harus berada di tengah-tengah artinya likuiditas tidak terlalu kecil (overliquid) atau terlalu besar (unliquid).

Likuiditas mengetat tidak menjadi masalah apabila porsi modal yang ditunjukkan dengan rasio Capital Adequacy Ratio (CAR) tinggi (Walfajri, 2018). Oleh karena itu, semakin tinggi kecukupan modal bank semakin tinggi pula tingkat likuiditas. Namun, dalam Laporan Keuangan Bank Umum 
Syariah tahun 2014-2019 terdapat beberapa bank syariah yang mengalami kecilnya ketersediaan kecukupan modal dibarengi dengan kenaikan tingkat likuiditas. Adapun ketika tingkat kecukupan modal naik justru tingkat likuiditas turun.

Sejumlah bank menyebutkan bahwa kecilnya likuiditas adalah untuk menjaga kualitas pembiayaan bermasalah atau Non Performing Financing (NPF) yang berarti ketika pembiayaan bermasalah meningkat, maka akan mengurangi kemampuan bank dalam menyalurkan pembiayaan atau likuiditas menurun, tetapi beberapa bank syariah juga mengalami kenaikan pembiayaan masalah dibarengi dengan kenaikan tingkat likuiditas bank.

Melihat perkembangan bank syariah yang sangat pesat, sehingga tidak menutup kemungkinan krisis akan berdampak pada perkembangan perbankan syariah di masa yang akan datang. Masalah likuiditas yang terjadi di bank syariah merupakan ancaman yang besar untuk bank syariah dalam menghadapi era globalisasi. Kestabilan tingkat inflasi sangat penting untuk mendukung kegiatan perekonomian masyarakat. Apabila tingkat inflasi stabil, maka dapat menimbulkan kepercayaan masyarakat dalam melakukan aktivitas ekonominya. Gejolak inflasi yang signifikan akan mengganggu kestabilan perekonomian. Dampak inflasi yang tinggi akan merugikan banyak golongan perekonomian (Veithzal \& Andria, 2007). Inflasi dapat menurunkan pemberian pembiayaan ke sektor riil, kalangan perbankan konvensional tetap dapat meraih pendapatan yang tinggi dari bunga SBI sehingga perbankan syariah tidak menempatkan likuiditasnya ke dalam SBI (Saekhu, 2015). Penelitian ini dilakukan untuk menganalisis faktor-faktor yang mempengaruhi tingkat likuiditas Bank Umum Syariah di Indonesia. Variabel yang digunakan dalam penelitian ini dibatasi oleh beberapa variabel saja. Variabel yang mempengaruhi tingkat likuiditas diantaranya tingkat kecukupan modal, tingkat pembiayaan bermasalah dan inflasi.

\section{Kajian Literatur}

Likuiditas adalah kemampuan perusahaan untuk memenuhi seluruh kewajiban yang harus dilunasi segera dalam waktu yang singkat. Sebuah perusahaan dikatakan likuid apabila mempunyai alat pembayaran berupa harta lancar yang lebih besar dibandingkan dengan kewajibannya, sehingga semakin mudah suat aset diperjualbelikan maka semakin tinggi tingkat likuidnya (Djauhari, 2012). Dari sudut aktiva, likuiditas merupakan kemampuan untuk mengubah seluruh aset menjadi bentuk tunai sedangkan dari sudut pasiva, likuiditas merupakan kemampuan bank dalam memenuhi kebutuhan dana melalui peningkatan portofolio liabilities (Arifin, 2009). Menurut (Muhammad, 2015) Financing to Deposit Ratio (FDR) adalah perbandingan antara pembiayaan yang diberikan oleh bank dengan dana pihak ketiga yang berhasil dikerahkan oleh bank. FDR menunjukan sejauh mana kemampuan bank syariah dalam membayar kembali penarikan dana yang telah dilakukan Fakultas Ekonomi dan Bisnis Islam - UIN Sunan Gunung Djati Bandung 
kepada nasabah. Pembayaran yang dilakukan oleh bank syariah kepada nasabah dilakukan dengan mengandalkan pembiayaan yang telah diberikan oleh bank syariah tersebut. Dengan kata lain, FDR digunakan untuk melihat seberapa jauh pembiayaan kepada nasabah dapat mengimbangi kewajiban untuk segera memenuhi hutang jangka pendek kepada nasabah yang ingin menarik kembali uangnya yang telah digunakan oleh bank untuk memberikan pembiayaan tersebut. Rumus Financing to Deposit Ratio adalah sebagai berikut:

$$
\text { Financing to Deposit Ratio }=\frac{\text { Pembiayaan }}{\text { Dana Pihak Ketiga }} \times 100 \%
$$

Semakin tinggi rasio FDR memberikan indikasi bahwa semakin rendahnya kemampuan likuiditas bank yang bersangkutan. Hal ini dikarenakan jumlah dana yang diperlukan untuk membiayai pembiayaan periode selanjutnya semakin kecil. Persaingan antara bank yang semakin ketat dan adanya ancaman likuiditas merupakan salah satu tentangan untuk perbankan. Menurut kesepakatan dalam Asosiasi Perbankan Syariah Indonesia (Asbindo) FDR yang ideal adalah kisaran 80\% hingga 90\% dinilai sebagai rasio FDR yang sehat (Wardana \& Widyarti, 2015).

Tingkat Kecukupan Modal (Capital Adequacy Ratio)

Kecukupan modal adalah suatu regulasi perbankan yang menetapkan suatu kerangka kerja mengenai bagaimana bank dan lembaga penyimpanan garus menangani permodalan mereka (Trianti, 2014).Capital Adequacy Ratio menunjukan seberapa besar modal bank yang telah memadai kebutuhannya dan sebagi dasar untuk menilai prospek kelanjutan usaha suat bank. Semakin besar Capital Adequacy Ratio maka akan semakin besar daya tahan bank yang bersangkutan dalam menghadapi penyusutan nilai harta bank yang timbul karena adanya harta bermasalah. Sesuai dengan peraturan Bank Indonesia Nomor 6/10/PBI/2004 tanggal 12 April 2004 tentang sistem penilaian tingkat kesehatan bank umum, semakin tinggi nilai Capital Adequacy Ratio menunjukan semakin sehat bank tersebut (Murzaki, 2012). Bank Indonesia menetapkan ketentuan modal minimum bagi perbankan sebagaimana ketentuan dalam standar Bank for International Stattlement (BIS) bahwa setiap bank wajib menyediakan modal sebesar $8 \%$ dari total Aktiva Tertimbang Menurut Risiko (ATMR).

Tingkat Pembiayaan Bermasalah (Non Performing Financing)

Pembiayaan bermasalah adalah pembiayaan yang menurut kualitas didasarkan atas risiko kemungkinan terhadap kondisi dan kepatuhan nasabah pembiayaan dalam memenuhi kewajiban untuk membayar bagi hasil, serta melunasi pembiayaan. Menurut (Usanti, 2013). Sasaran kebijakan risiko pembiayaan adalah mengidentifikasi, mengukur, memantau dan mengendalikan jalannya kegiatan usaha bank dengan tingkat risiko yang wajar secara terarah, integrasi dan berkesinambungan sehingga manajemen risiko berfungsi sebagai filter atau memberi peringatan Fakultas Ekonomi dan Bisnis Islam - UIN Sunan Gunung Djati Bandung 
dini terhadap usaha bank (Antonio, 2010). NPF adalah rasio yang menunjukan kemampuan manajemen bank dalam mengelola pembiayaan bermasalah, sehingga semakin tinggi rasio ini menunjukan semakin buruk kualitas pembiayaan bank yang menyebabkan jumlah pembiayaan bermasalah semakin besar.

Inflasi dapat diartikan sebagai gejala kenaikan harga barang-barang yang bersifat umum dan terus menerus. Dari definisi ini ada tiga syarat untuk dapat dikatakan telah terjadi inflasi. Pertama, adanya kenaikan harga. Kedua, kenaikan tersebut terjadi terhadap harga-harga barang secara umum. Ketiga, kenaikan tersebut berlangsung cukup lama. Dengan demikian kenaikan harga yang terjadi pada hanya satu jenis barang atau kenaikan yang terjadi hanya sementara waktu tidak dapat disebut dengan inflasi (Rahardja \& Manurung, 2004).

Berdasarkan indeks harga konsumen dapat dihitung beberapa besarnya kenaikan laju harga-harga secara umum dalam periode tertentu. Biasanya setiap bulan, 3 bulan dan 1 tahun. Selain menggunakan IHK, tingkat inflasi juga dapat dihitung dengan menggunakan GNP atau PDB deflator yaitu membandingkan GNP atau PDB yang diukur berdasarkan harga berlaku (GNP atau PDB nominal) terhadap GNP atau PDB harga konstan (GNP atau PDB riil).

\section{Metode}

Metode penelitian yang digunakan dalam penelitian ini adalah metode deskriptif kuantitatif. Populasi pada penelitian ini sebanyak 14 Bank Umum Syariah yang terdaftar di Otoritas Jasa Keuangan (OJK). Teknik pengambilan sampel menggunakan purposive sampling sehingga sampel dalam penelitian ini adalah 12 bank syariah periode 2014-2019. Data yang digunakan dalam penelitian ini merupakan data sekunder yaitu data yang sudah tersedia sebelumnya. Data diambil dari website resmi Bank Umum Syariah yang terdaftar di Otoritas Jasa Keuangan berupa laporan keuangan bank syariah dilampirkan dari periode 2014-2019. Analisis data dalam penelitian ini menggunakan data panel yang merupakan gabungan dari data runtut waktu (time series) dan data silang (cross section) (Basuki \& Yuliadi, Ekonometrika Teori \& Aplikasi, 2015). Pengujian hipotesis dilakukan dengan model regresi data panel dan pengolahan data dalam penelitian ini menggunakan softwere Eviews Versi 9.

\section{Result and Discussion}

Likuiditas Bank Umum Syariah di Indonesia pada tahun 2014-2019 berfluktuatif dan cenderung meningkat. Tingkat likuiditas yang diperoleh BUS berada di atas batas ideal dan menunjukkan bahwa likuiditas BUS tidak sehat. Untuk lebih jelasnya dapat dilihat pada gambar berikut ini : 


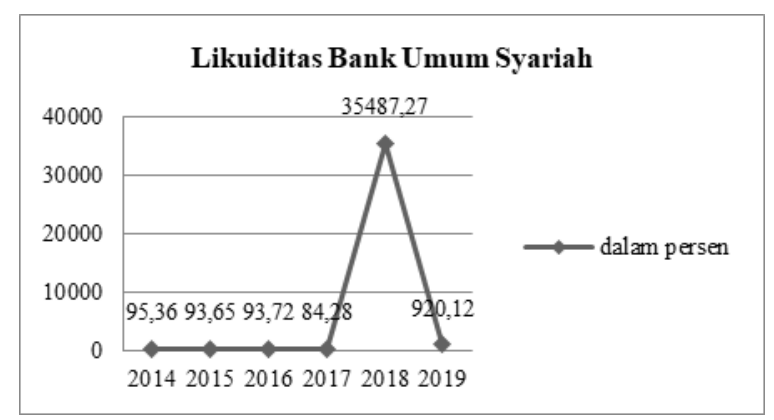

Gambar 4. 1 Grafik Perkembangan Tingkat Likuiditas Bank Umum Syariah Tahun 2014-2019

Sumber: Laporan keuangan BUS tahun 2014-2019

Tingkat likuiditas yang ditunjukan dengan rasio FDR Bank Umum Syariah di Indonesia pada tahun 2014-2019 berfluktuatif dan cenderung meningkat yaitu 95,36\% - 920,12 \% hal ini berarti likuiditas BUS berada di atas batas ideal dan menunjukkan bahwa likuiditas BUS tidak sehat. Tingkat Likuiditas terrendah pada tahun 2014-2019 yaitu 84,28\% tetapi penurunan ini masih berada pada batas yang ideal yaitu masih di antara kisaran $80 \%-110 \%$, hal ini berarti bank menjalankan fungsi intermediasi dengan baik karena dananya lebih banyak disalurkan dalam bentuk pembiayaan bukan investasi atau kegiatan non pembiayaan. Sedangkan tingkat likuiditas tertinggi pada tahun 2018 mencapai 35487,27\% FDR bank syariah melebihi batas ideal yang berarti bank melakukan pembiayaan yang berlebihan, sehingga dana yang tersedia di bank tersebut berkurang padahal selain pembiayaan bank harus memenuhi kewajiban operasional kepada nasabah (Rizkiyah, Yuniawati, \& Wiyanti, 2018). Tingkat kecukupan modal Bank Umum Syariah tahun 2014-2019 berfluktuatif cenderung meningkat dengan kategori sehat, Seperti pada tahun 2019 kecukupan modal memperoleh nilai tertinggi sebesar $40.11 \%$. Sedangkan tingkat kecukupan modal terendah terjadi pada tahun 2018 yaitu $18.74 \%$. Untuk lebih jelasnya dapat dilihat pada gambar berikut ini :

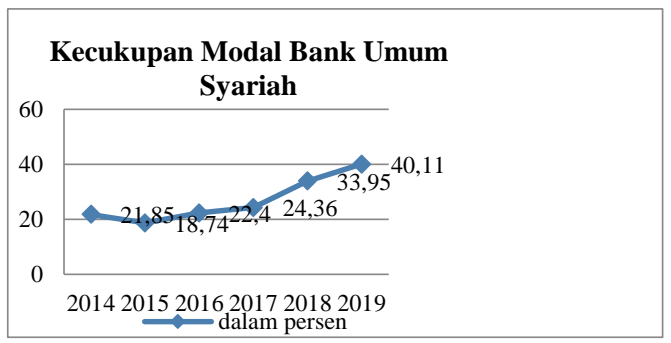

Gambar 4. 1 Grafik Perkembangan Tingkat Kecukupan Modal Bank Umum Syariah Tahun 20142019

Sumber: Laporan Keuangan Bank Umum Syariah Tahun 2014-2019

Perkembangan tingkat kecukupan modal Bank Umum Syariah tahun 2014-2019 berfluktuatif cenderung meningkat dengan kategori sehat, seperti pada tahun 2019 kecukupan modal Fakultas Ekonomi dan Bisnis Islam - UIN Sunan Gunung Djati Bandung 
memperoleh nilai tertinggi sebesar 40,11\%. Sedangkan pada tahun 2014 mengalami penurunan sebesar 18,74\% dari tahun sebelumnya sebesar 21,85\%. Namun pada tahun 2016 hingga 2019 kecukupan modal yang ditunjukan dengan rasio Capital Adequacy Ratio (CAR) mengalami peningkatan.

Pembiayaan bermasalah BUS selama enam tahun yaitu tahun 2014-2019 mengalami fluktuatif dan cenderung menurun sehingga tingkat pembiayaan bermasalah BUS masuk dalam kriteria sehat. NPF tertinggi pada tahun 2017 sebesar 4.09 sedangkan NPF terrendah pada tahun 2019 yaitu 2.21\%. Untuk lebih jelasnya dapat dilihat pada gambar berikut ini :

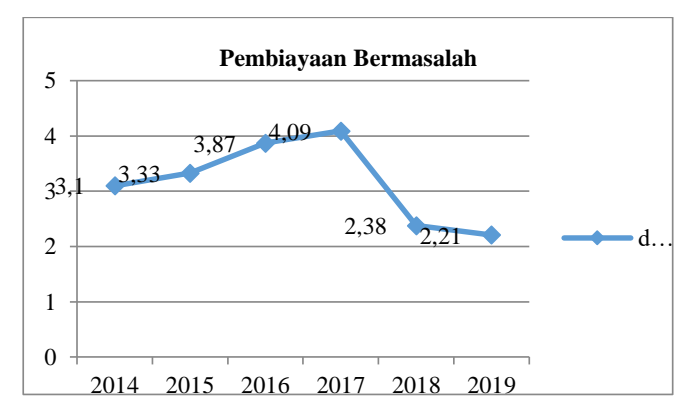

Gambar 4. 2 Grafik Perkembangan Pembiayaan Bermasalah Bank Umum Syariah Tahun 2014-2019

Sumber: Laporan Keuangan Bank Umum Syariah Tahun 2014-2019

Tingkat pembiayaan bermasalah BUS selama enam tahun yaitu tahun 2014-2019 mengalami fluktuatif dan cenderung menurun sehingga pembiayaan bermasalah BUS masuk dalam kriteria sehat hal ini ditunjukan dengan NPF pada tahun 2019 sebesar 2,21\%. Pembiayaan masalah terendah dialami pada tahun 2016 yaitu mencapai 4.06\%. Semakin tinggi tingkat NPF maka semakin tidak baik kualitas bank tersebut.

Inflasi di Indonesia pada tahun 2014-2019 mengalami fluktuatif cenderung menurun dengan kategori inflasi rendah. Inflasi tertinggi terjadi pada tahun 2014 yaitu 8.36\% namun masih dalam kategori rendah. Sedangkan inflasi terrendah terjadi pada tahun 2019 yaitu 2.72\% dengan kategori rendah. Untuk lebih jelasnya dapat dilihat pada gambar berikut ini:

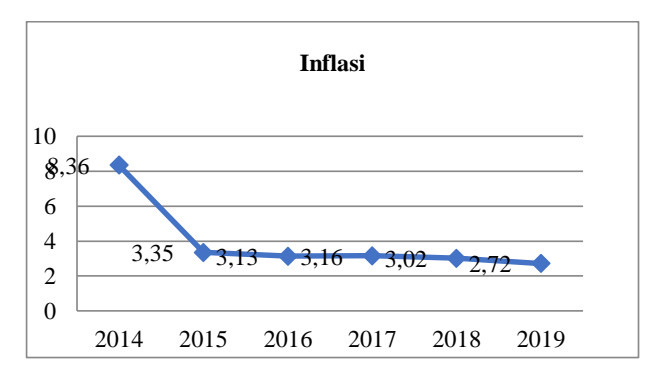

Gambar 4. 3 Grafik Perkembangan Inflasi Indonesia

Fakultas Ekonomi dan Bisnis Islam - UIN Sunan Gunung Djati Bandung 
Tahun 2014-2019

Sumber : Badan Pusat Statistik 2014-2019

Multikolinearitas adalah kondisi adanya hubungan linear antar variabel independen. Hasil uji multikolinearitas akan disajikan sebagai berikut:

Tabel 4. 1 Uji Multikolinearitas

Sumber : Data Hasil Penelitian (2020)

\begin{tabular}{cccc}
\hline & CAR & NPF & INFLASI \\
\hline & \multicolumn{4}{c}{0.2226005} & - \\
CAR & 1 & 9 & -09384191 \\
& - & & \\
& 0.2226005 & & 0.01596291 \\
NPF & 9 & 1 & 0 \\
& - & & \\
& 0.093841 & 0.0159629 & \\
INFLASI & 918 & 10 & 1 \\
\hline
\end{tabular}

Tabel 4. 2 Uji Heteroskedastisitas

Sumber : Data Hasil Penelitian (2020)

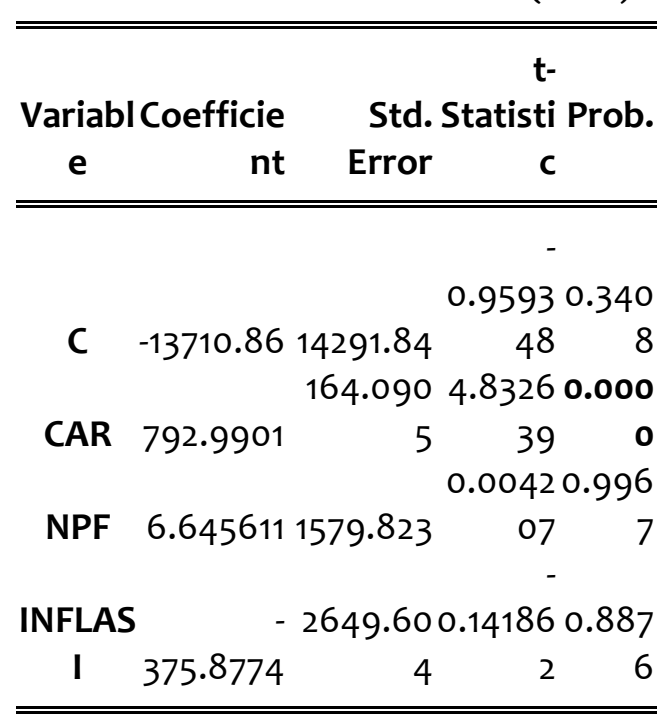

Berdasarkan tabel di atas terdapat salah satu variabel independen yang memiliki nilai signifikansi $\leq$ 0.05 yang artinya model tersebut terkena heteroskedastisitas. Untuk memperbaiki data yang terkena heteroskedastisitas maka dilakukakan uji white. Adapun hasil dari pengujian tersebut adalah sebagai berikut:

Tabel 4. 3 Uji White

Sumber: Data Hasil Penelitian (2020)

Dependent Variable: $\mathrm{RESID}^{\wedge} 2$

Method: Panel Least Squares

Date: 07/18/20 Time: 00:10

Fakultas Ekonomi dan Bisnis Islam - UIN Sunan Gunung Djati Bandung 


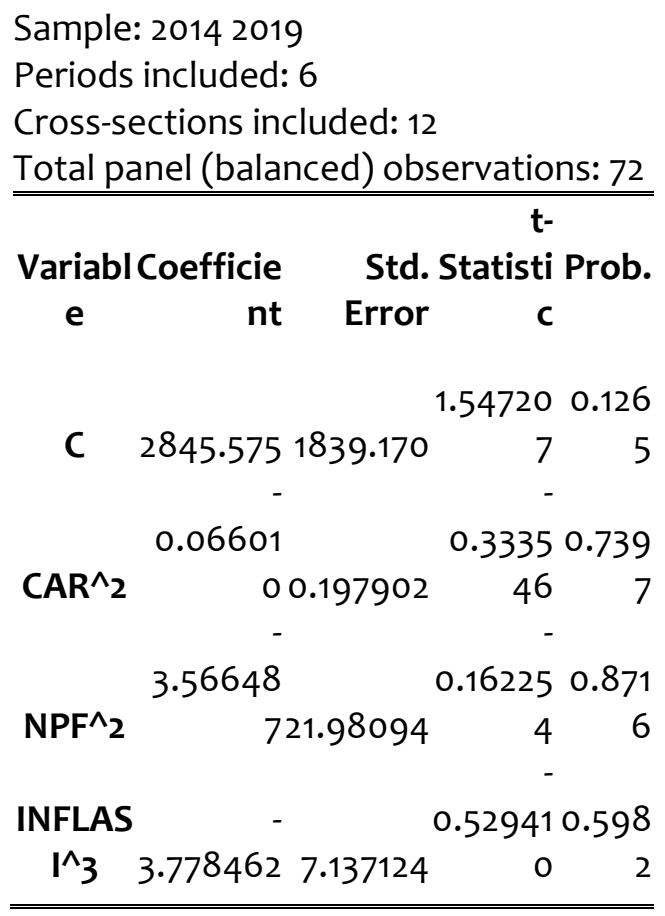

Hasil uji heteroskedastisitas dengan menggunakan uji white menunjukkan bahwa nilai signifikansi lebih > 0,05 maka berdasarkan kriteria pengujian keputusan yang diambil adalah data tidak mengalami heteroskedastisitas.

Chow Test digunakan untuk memilih kedua model yang paling tepat untuk digunakan dalam regresi data panel antara model Common Effect dan model Fixed Effect. Berikut adalah hasil uji chow :

Tabel 4. 4 Uji Chow

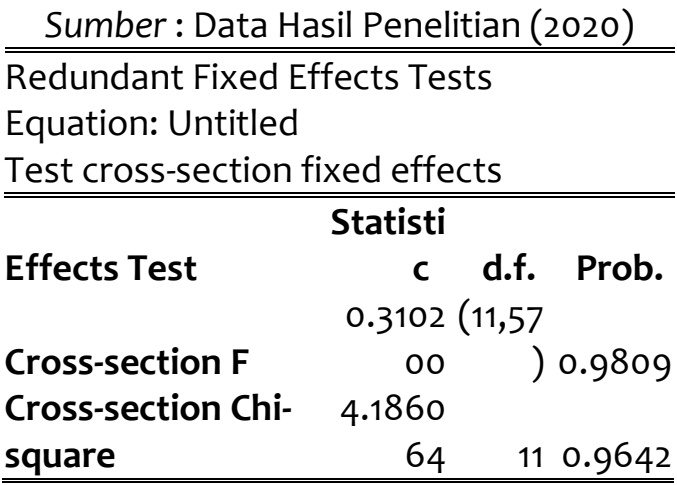

Tabel 4. 5 Uji Hausman Sumber : Data Hasil Penelitian

Correlated Random Effects - Hausman

Test

Equation: Untitled

Test cross-section random effects

\begin{tabular}{lrr}
\hline & Chi-Sq. & Chi-Sq. \\
\hline Test Summary & Statistic & d.f.Prob. \\
\hline
\end{tabular}

Fakultas Ekonomi dan Bisnis Islam - UIN Sunan Gunung Djati Bandung 


\begin{tabular}{lrrr}
\hline \hline Cross-section & \multicolumn{2}{r}{0.636} \\
random & 1.703260 & 3 & 2 \\
\hline \hline
\end{tabular}

Uji Lagrange Multiplier adalah analisis yang digunakan dengan tujuan untuk menentukan metode yang terbaik dalam regresi data panel apakah akan menggunakan Common effect atau random effect.

Tabel 4. 6 Uji Lagrange Multiplier Sumber : Data hasil penelitian (2020)

\begin{tabular}{|c|c|c|c|}
\hline \multicolumn{4}{|c|}{$\begin{array}{l}\text { Lagrange Multiplier Tests for Random Effects } \\
\text { Null hypotheses: No effects } \\
\text { Alternative hypotheses: Two-sided (Breusch- } \\
\text { Pagan) and one-sided } \\
\quad \text { (all others) alternatives } \\
\end{array}$} \\
\hline \multirow{4}{*}{$\begin{array}{l}\text { Breusch- } \\
\text { Pagan }\end{array}$} & \multicolumn{3}{|c|}{ Test Hypothesis } \\
\hline & $\begin{array}{l}\text { Cross- } \\
\text { section }\end{array}$ & Time & Both \\
\hline & & 0.1186 & \\
\hline & $\begin{array}{l}4.077901 \\
(0.0434)\end{array}$ & $\begin{array}{c}86 \\
(0.7305 \\
)\end{array}$ & $\begin{array}{l}4.196587 \\
(0.0405)\end{array}$ \\
\hline
\end{tabular}

Hasil dari data di atas menunjukkan nilai probabilitas Breusch-Pagan sebesar 0.0434 atau BP $<0.05$ yang artinya Ho ditolak. Maka model yang cocok digunakan dalam penelitian ini adalah Random Effect Model.

Dari serangkaian pengujian chow test, hausman test dan lagrange multiplier untuk menentukan model regresi yang sesuai digunakan maka ketiga uji tersebut menentukan bahwa model regresi Random Effect adalah model yang paling baik digunakan dengan hasil estimasi sebagai berikut :

Tabel 4. 7 Hasil Random Effec Model Sumber : Data hasil penelitian (2020)

Dependent Variable: FDR

Method: Panel EGLS (Cross-section random effects)

Date: 07/18/20 Time: 23:15

Sample: 20142019

Periods included: 6

Cross-sections included: 12

Total panel (balanced) observations: 72

Swamy and Arora estimator of component variances

\begin{tabular}{crcc} 
& & \multicolumn{2}{c}{$\mathrm{t}-$} \\
Variable & Coefficie & Std. Statisti \\
nt & Error $\quad$ c Prob.
\end{tabular}

Fakultas Ekonomi dan Bisnis Islam - UIN Sunan Gunung Djati Bandung 


\begin{tabular}{crrrr} 
& 3.80535 & \multicolumn{2}{c}{17.2016} \\
C & 8 & 0.221221 & 30.0000 \\
CAR & 0.02970 & 0.0025411 .6949 & \\
& 8 & 0 & 30.0000 \\
NPF & 0.015678 & 0.02446 & 0.6409 & \\
& 0.00403 & 16 & 0.5237 \\
INFLASI & 6 & 0.041019 & 83 & 0.9219 \\
\hline \hline & Effects & & \\
Specification
\end{tabular}

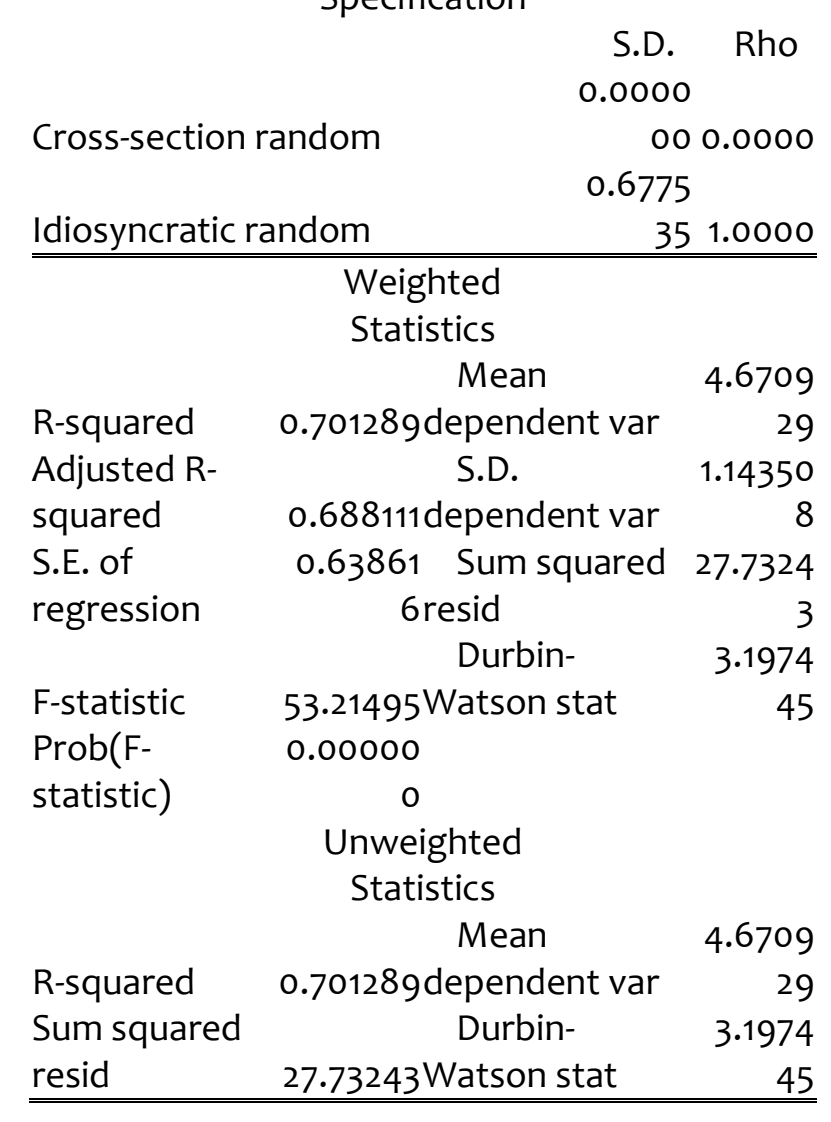

Persamaan regresi memuat nilai konstanta pada setiap variabel penelitian. Penjelasan dari masingmasing koefisien variabel adalah sebagai berikut :

$$
\begin{gathered}
\text { FDRit }=3.80535751173+0.0297081822906 * \mathrm{CAR} \\
+0.0156778529372 * \mathrm{NPF}+0.00403556777561 * \mathrm{IN} \\
\text { FLASI }+\varepsilon_{i t}
\end{gathered}
$$

$$
Y_{i t}=a+X^{1}{ }_{i t} \beta_{i t}+\varepsilon_{i t}
$$

Dalam pendekatan ini, intersep dan slope adalah tetap sepanjang waktu dan individu, adanya perbedaan intersep dan slope diasumsikan akan dijelaskan oleh variabel gangguan (error atau residual). Dari hasil regresi pada model Common effect model didapatkan bahwa koefisien pada Fakultas Ekonomi dan Bisnis Islam - UIN Sunan Gunung Djati Bandung 
$\mathrm{CAR}=74384.96, \mathrm{NPF}=206.9084$ dan inflasi $=$ 533.9266. Adapun penjelasan dari masing-masing koefisien variabel sebagai berikut :

\begin{tabular}{|c|c|}
\hline 3.805358 & $\begin{array}{l}\text { : Jika X1 (CAR), X2 (NPF) dan X3 (inflasi) adalah nol, maka } \\
\text { (FDR) sebesar } 3.80 \%\end{array}$ \\
\hline 0.029708 & $\begin{array}{l}\text { : Jika mengalami perubahan } X_{1} \text { (Kecukupan Modal) sebesar satu } \\
\text { persen, maka Y (FDR) akan turun sebesar } 0.02 \% \text {. }\end{array}$ \\
\hline 0.0156778 & $\begin{array}{l}\text { : Jika mengalami perubahan X2 (NPF) sebesar satu persen, maka } \\
\text { Y (ROA) akan turun sebesar } 0.01 \% \text {. }\end{array}$ \\
\hline 0.004036 & $\begin{array}{l}\text { : Jika mengalami perubahan } X_{3} \text { (inflasi) sebesar satu persen, maka } \\
\text { Y (FDR) akan mengalami kenaikan sebesar } 0.00 \% \text { dengan asumsi } \\
\text { variable lain tetap. }\end{array}$ \\
\hline R-square & $\begin{array}{l}: 0.701289 \text { artinya tingkat kedekatan pengaruh variabel bebas } \\
\text { terhadap variabel terikat sebesar } 70 \% \text { sedangkan sebesar } 30 \% \\
\text { dipengaruhi oleh faktor-faktor lain yang tidak dimasukan dalam } \\
\text { penelitian. }\end{array}$ \\
\hline Adjuster R-sc & $\begin{array}{l}\text { : } 0.688111 \text { artinya nilai } R 2 \text { yang sudah disesuaikan semakin banyak } \\
\text { variabel bebas yang masuk ke dalam permasamaan maka nilai } R 2 \\
\text { semakin kecil. }\end{array}$ \\
\hline S.E. of Regression & $\begin{array}{l}\text { : } 0.638616 \text { artinya banyaknya kesalahan dalam memprediksi } \\
\text { likuiditas adalah sebesar } 60.38 \% \text {. }\end{array}$ \\
\hline F-statistic & $\begin{array}{l}\text { : } 53.21495 \text { lebih besar dari F-tabel sebesar } 2.74 \text { dapat disimpulkan } \\
\text { bahwa kecukupan modal, pembiayaan bermasalah dan inflasi } \\
\text { berpengaruh terhadap likuiditas. }\end{array}$ \\
\hline Prob (F-statistic) & $\begin{array}{l}\text { : } 0.000000 \text { variabel independen yaitu kecukupan modal, } \\
\text { pembiayaan bermasalah dan inflasi yang dimasukan dalam model } \\
\text { mempunyai pengaruh terhadap variabel dependen terhadap } \\
\text { likuiditas. }\end{array}$ \\
\hline Mean dependent var & $\begin{array}{l}\text { : } 4.670929 \text { artinya rata-rata likuiditas Bank Umum Syariah yang } \\
\text { diperoleh investor sebesar } 4.670929 \text {. }\end{array}$ \\
\hline S. & $\begin{array}{l}: 1.143508 \text { artinya likuiditas menyimpang kurang lebih } 3.197445 \\
\text { dari rata-rata likuiditas secara keseluruhan. }\end{array}$ \\
\hline
\end{tabular}

Uji $\mathrm{F}$ statistik digunakan untuk menguji keberartian regresi. Nilai $\mathrm{F}$ tabel diperoleh dengan ketentuan N2=n - k dan N1 = k-1. Dimana $n$ adalah jumlah observasi dan $\mathrm{k}$ adalah jumlah variabel. Jadi nilai $\mathrm{F}$ tabel digunakan dalam penelitian ini adalah $\mathrm{N} 2=77-4=68$ dan $\mathrm{N} 1=4-1=3$ dan $\alpha=$ 0.05, maka nilai $\mathrm{F}$ tabel yang dugunakan adalah 2.74 .

Adapun ketentuan uji f adalah sebagai berikut :

Jika F hitung $>$ F tabel atau SIG F $<0.05$ maka Ho ditolak.

Jika F hitung $\leq \mathrm{F}$ tabel atau SIG F > 0.05, maka Ho diterima.

Dengan hipotesis :

Ho : Regresi tidak berarti

$\mathrm{H} 1$ : Regresi berarti

Fakultas Ekonomi dan Bisnis Islam - UIN Sunan Gunung Djati Bandung 
Tabel 4. 8 Uji F

Sumber : Data hasil penelitian 2020

\begin{tabular}{lr}
\hline F-statistic & 13.08013 \\
\hline Prob(F-statistic) & 0.000000 \\
\hline
\end{tabular}

Berdasarkan tabel 4.12 diketahui bahwa F-statistic 13.08013 lebih besar dari F tabel 2.73 dan probabilitasnya 0.0000 lebih kecil dari tingkat signifikansi 0.05. maka Ho ditolak dan H1 diterima sehingga dapat disimpulkan bahwa regresi berarti, yang artinya bahwa regresi dapat digunakan untuk mengambil kesimpulan.

Ho : $\beta 1=0$, tidak terdapat pengaruh tingkat kecukupan modal terhadap tingkat likuiditas.

$\mathrm{Ho}: \beta 1 \neq 0$, terdapat pengaruh tingkat kecukupan modal terhadap tingkat likuiditas.

Tabel 4. 9 Hasil Uji t Tingkat Kecukupan Modal Terhadap Tingkat Likuiditas Sumber : Data hasil penelitian (2020)

\begin{tabular}{crccr}
\hline \hline & & \multicolumn{3}{c}{$t-$} \\
Variable & Coefficie & \multicolumn{2}{c}{ Std. Statisti Prob. } \\
& nt & Error & c \\
CAR & 0.02970 & 0.0025411 .69490 .000 \\
\hline \hline
\end{tabular}

Berdasarkan tabel 4.13 menunjukkan bahwa nilai t hitung sebesar 11.69493 lebih besar dari t tabel sebesar 1.99547 yang artinya Ho diterima dan H1 ditolak. Selanjutnya tingkat probabilitas sebesar 0.0000 lebih kecil dari $\alpha=0.05$. maka dari itu, dapat disimpulkan bahwa tingkat kecukupan modal berpengaruh terhadap tingkat likuiditas dengan arah yang positif, hal ini menunjukkan bahwa setiap peningkatan kecukupan modal sebesar satu persen maka akan berpengaruh terhadap peningkatan tingkat likuiditas sebesar $1.39 \%$.

$\mathrm{Ho}: \beta 1=0$, tidak terdapat pengaruh tingkat pembiayaan bermasalah terhadap likuiditas.

$\mathrm{Ho}: \beta 1 \neq 0$, terdapat pengaruh tingkat pembiayaan bermasalah terhadap likuiditas

Tabel 4. 10 Hasil uji t Pengaruh Tingkat Pembiayaan Bermasalah Terhadap Tingkat Likuiditas

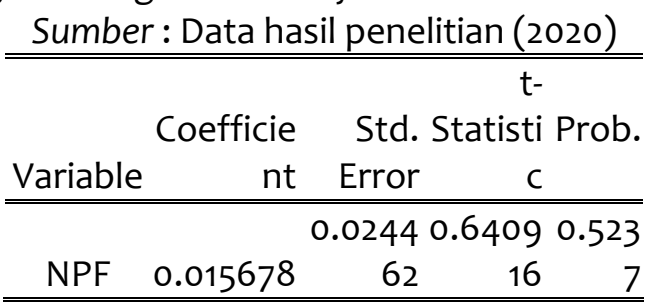

Ho : $\beta 1=0$, tidak terdapat pengaruh tingkat pembiayaan bermasalah terhadap tingkat likuiditas. $\mathrm{Ho}: \beta 1 \neq 0$, terdapat pengaruh pembiayaan bermasalah terhadap tingkat likuiditas.

Tabel 4. 11 Hasil Uji t Inflasi terhadap Tingkat Likuiditas Sumber : Data hasil penelitian (2020)

Fakultas Ekonomi dan Bisnis Islam - UIN Sunan Gunung Djati Bandung 


\begin{tabular}{lrrrr}
\hline \hline & & \multicolumn{3}{c}{$t-$} \\
Variable & Coeffici & \multicolumn{2}{c}{ Std.Statisti Prob. } \\
ent & Error & \multicolumn{1}{c}{ c } \\
\hline & 0.00403 & 0.041010 .0983 & 0.921 \\
INFLASI & 6 & 9 & 83 & 9 \\
\hline \hline
\end{tabular}

Berdasarkan data pada kondisi aktual, tingkat kecukupan modal pada 12 Bank Umum syariah secara keseluruhan berfluktuatif cenderung meningkat setiap tahunnya dengan rata-rata sebesar 56,61\%. Semakin tinggi CAR maka semakin besar pula sumber daya finansial yang dapat digunakan untuk mengantisipasi potensi kerugian yang diakibatkan oleh penyaluran pembiayaan sehingga likuiditas akan meningkat. Dengan demikian, dari hasil tersebut sesuai dengan teori dan penelitian sebelumnya yang digunakan dalam penelitian. Hal ini menunjukkan bahwa tingkat kecukupan modal (CAR) berpengaruh positif terhadap tingkat likuiditas (FDR) pada Bank Umum Syariah.

Berdasarkan hasil penelitian Random Effec Model pada tabel menunjukkan bahwa nilai t hitung sebesar 11.69493 lebih besar dari t tabel sebesar 1.99547 dan probabilitas sebesar 0.0000 lebih kecil dari $\alpha=0.05$, hal ini menandakan bahwa tingkatkecukupan modal berpengaruh terhadap tingkat likuiditas. Hal ini mengindikasikan bahwa setiap adanya peningkatan tingkat kecukupan modal (CAR) maka akan berpengaruh terhadap peningkatan pembiayaan dan tingkat likuiditas. Besarnya modal suatu bank akan berpengaruh pada baik atau tidaknya suatu bank secara efisien menjalankan kegiatannya dan dapat mempengaruhi tingkat kepercayaan masyarakat terhadap kinerja bank.

Penelitian ini sejalan dengan penelitian yang telah dilakukan oleh (Faturrahman \& Rusdi, 2019), (Prakoso, 2017), (Amelia \& Murtasih, 2017), (Hersugondo \& Tamtomo, 2012) dan (Nandadipa, 2010) bahwa CAR mempunyai pengaruh terhadap likuiditas (FDR). Dengan meningkatnya kualitas CAR akan menjadi pengaruh pada tingkat likuiditas Bank Umum Syariah. Namun penelitian ini tidak sejalan dengan penelitian yang dilakukan oleh (Ervina \& Adriansyah, 2016) (Nursuhartatik \& Kusumaningtias, 2019) yang menyatakan bahwa CAR tidak berpengaruh terhadap FDR. Rasio kecukupan modal yang harus ada pada setiap bank sebagai pembangunan usaha dan menampung risiko kerugian usaha bank merupakan pembagian dari modal dengan total Aktiva Tertimbang Menurut Risiko (ATMR). Berdasarkan ketentuan Bank Indonesia, bank dinyatakan termasuk sebagai bank yang sehat haru memiliki CAR paling sedikit $8 \%$. Hal ini didasarkan pada ketentuan yang ditetapkan oleh Bank Indonesia sebagai standar tingkat kesehatan bank untuk permodalan. Bank yang memiliki CAR tinggi maka pembiayaannya juga banyak sehingga apabila CAR meningkat maka akan meningkatkan FDR. Dengan demikian, berdasarkan hasil temuan dalam penelitian ini Fakultas Ekonomi dan Bisnis Islam - UIN Sunan Gunung Djati Bandung 
yang dikaitkan dengan konsep teoritis dan didukung fakta empiris penelitian sebelumnya dapat disimpulkan bahwa kecukupan modal berpengaruh positif terhadap likuiditas Bank Umum Syariah sehingga dari hasil penelitian ini sudah sesuai dan mendukung beberapa hasil penelitian sebelumnya.

Berdasarkan data kondisi aktual rata-rata pembiayaan bermasalah BUS selama enam tahun yaitu tahun 2014-2019 mengalami peningkatan dan masuk dalam kriteria baik yaitu 2,21\% pada tahun 2019 dan pembiayaan masalah terendah dialami pada tahun 2016 yaitu mencapai 4.06\%. Semakin tinggi pembiayaan bermasalah, maka akan mengurangi kemampuan bank dalam menyalurkan pembiayaan atau likuiditas menurun. Dalam penelitian ini variabel pembiayaan bermasalah (NPF) memiliki nilai $t$ hitung sebesar 0.640916 lebih kecil dari t tabel sebesar 1.99547 dan probabilitas sebesar 0.0000 lebih kecil dari $\alpha=0.05$, maka hasil dari penelitian ini dapat disimpulkan bahwa nilai signifikan lebih besar dari tingkat signifikan yang telah ditentukan yaitu 0.05. Hasil penelitian ini menunjukkan bahwa tingkat pembiayaan bermasalah tidak berpengaruh terhadaptingkat likuiditas. Penelitian ini sejalan dengan penelitian yang dilakukan (Waemustafa \& Sukri, 2016), (Ervina \& Adriansyah, 2016) dan (Fikriati, 2015) yang menyatakan bahwa NPF tidak berpengaruh terhadap tingkat likuiditas bank umum syariah. NPF tidak berpengaruh terhadap FDR karena perbankan syariah tidak akan melakukan pengetatan pembiayaan hanya karena nilai NPF meningkat, sebab pengetatan pembiayaan tidak akan menghasilkan keuntungan untuk perbankan. Maka dari itu, bank akan tetap berjalan meskipun NPF yang dimiliki bank mengalami peningkatan atau penurunan. Selain itu, hasil pengujian ini terjadi karena rata-rata nilai NPF Bank Umum Syariah yang menjadi sampel penelitian masih dalam batas maksimum NPF yang ditentukan oleh Bank Indoneisa. Hasil rata-rata NPF pada Bank Umum Syariah dalam penelitian ini yaitu sebesar 2,21\% dengan kategori sehat.

Namun penelitian ini tidak sejalan dengan penelitian yang dilakukan oleh (Utami \& Muslikhati, 2019), (Nursuhartatik \& Kusumaningtias, 2019) dan (Somantri \& Sukmana, 2019) yang menyatakan bahwa pembiayaan bermasalah (NPF) berpengaruh terhadap likuiditas Bank Umum Syariah. Berdasarkan hasil penelitian (Nursuhartatik \& Kusumaningtias, 2019) NPF merupakan masalah pembiayaan yang diakibatkan karena deposan tidak dapat membayar tagihan atau pembiayaan, sehinga besarnya NPF menjadi salah satu penyebab sulitnya perbankan dalam menyalurkan pembiayaan. Dengan demikian, berdasarkan hasil temuan dalam penelitian ini yang dikaitkan dengan konsep teoritis dan didukung fakta empiris penelitian sebelumnya dapat disimpulkan bahwa pembiayaan bermasalah tidak berpengaruh terhadap likuiditas Bank Umum Syariah, Fakultas Ekonomi dan Bisnis Islam - UIN Sunan Gunung Djati Bandung 
sehingga dari hasil penelitian ini tidak sesuai dengan teori dan mendukung beberapa hasil penelitian sebelumnya.

Berdasarkan data aktual perkembangan inflasi di Indonesia pada tahun 2014-2019 mengalami fluktuatif cenderung menurun. Pada tahun 2015 inflasi mengalami penurunan 3,35\% dari 2014 sebesar $8,36 \%$, Indonesia mengalami kenaikan serta penurunan angka inflasi setiap tahunnya. Hal ini dikarenakan adanya faktor musiman baik di bahan makanan jadi ataupun transpotasi yang menyebabkan naiknya harga bahan bakar pesawat atau avtur sehingga berimbas pada kenaikan harga tiket pesawat.

Dalam penelitian ini variabel inflasi memiliki nilai t hitung 0.098383 lebih kecil dari 1.99547 yang dan probabilitas sebesar 0.9219 lebih besar dari $\alpha=0.05$. Dapat disimpulkan bahwa inflasi tidak berpengaruh terhadap likuiditas. Hal ini menunjukkan bahwa setiap kenaikan inflasi sebesar satu persen tidak ada penurunan atau peningkatan likuiditas. Inflasi tidak berpengaruh terhadap FDR karena bank syariah tidak memakai mekanisme suku bunga, sehingga tingkat bagi hasil atau margin laba produk bank syariah tidak harus menyesuaikan dengan tingkat inflasi seperti halnya tingkat suku bunga bank konvensional. Hal ini sejalan dengan penelitian yang dilakukan oleh (Rani, 2017), (Saekhu, 2013)dan (Fikriati, 2015) yang menyatakan bahwa inflasi tidak berpengaruh terhadap likuiditas Bank Umum Syariah. Selain itu, meningkatnya laju infalsi tidak akan mengurangai kegiatan bank syariah dalam menyalurkan dana yang dihimpunnya. Hal ini disebabkan kondisi inflasi pada periode penelitian relatif stabil dan inflasi yang terjadi adalah inflasi ringan yaitu di bawah $10 \%$ pertahunnya.

Namun berbeda dengan hasil penelitian yang dilakukan oleh (Nandadipa, 2010), (Novitasari, 2016) (Faturrahman \& Rusdi, 2019) yang menyatakan bahwa inflasi berpengaruh terhadap likuiditas Bank Umum Syariah. Dengan demikian, berdasarkan hasil temuan dalam penelitian ini yang dikaitkan dengan konsep teoritis dan didukung fakta empiris penelitian sebelumnya dapat disimpulkan bahwa inflasi tidak berpengaruh terhadap tingkat likuiditas Bank Umum Syariah, sehingga dari hasil penelitian ini tidak sesuai dan mendukung beberapa hasil penelitian sebelumnya.

\section{KESIMPULAN}

Tingkat likuiditas yang ditunjukan dengan rasio FDR Bank Umum Syariah di Indonesia pada tahun 2014-2019 berfluktuatif dan cenderung meningkat berada di atas batas ideal dan menunjukkan bahwa tingkat likuiditas BUS tidak sehat. Tingkat kecukupan modal Bank Umum Syariah tahun 2014-2019 berfluktuatif cenderung meningkat dengan kategori sehat. Tingkat pembiayaan bermasalah BUS selama enam tahun yaitu tahun 2014-2019 mengalami fluktuatif dan cenderung Fakultas Ekonomi dan Bisnis Islam - UIN Sunan Gunung Djati Bandung 
menurun sehingga pembiayaan bermasalah BUS masuk dalam kriteria sehat. perkembangan inflasi di Indonesia pada tahun 2014-2019 mengalami fluktuatif cenderung menurun dengan kategori inflasi rendah.

Tingkat kecukupan modal berpengaruh terhadap tingkat likuiditas. Hal ini mengindikasikan bahwa setiap adanya peningkatan tingkat kecukupan modal (CAR) maka akan berpengaruh terhadap peningkatan pembiayaan dan tingkat likuiditas. Besarnya modal suatu bank akan berpengaruh pada baik atau tidaknya suatu bank secara efisien menjalankan kegiatannya dan dapat mempengaruhi tingkat kepercayaan masyarakat terhadap kinerja bank.

Pembiayaan bermasalah tidak berpengaruh terhadap tingkat likuiditas. NPF tidak berpengaruh terhadap FDR karena perbankan syariah tidak akan melakukan pengetatan pembiayaan hanya karena nilai NPF meningkat, sebab pengetatan pembiayaan tidak akan menghasilkan keuntungan untuk perbankan. Maka dari itu, bank akan tetap berjalan meskipun NPF yang dimiliki bank mengalami peningkatan atau penurunan. Selain itu, hasil pengujian ini terjadi karena rata-rata nilai NPF Bank Umum Syariah yang menjadi sampel penelitian masih dalam batas maksimum NPF yang ditentukan oleh Bank Indoneisa. Hasil rata-rata NPF pada Bank Umum Syariah dalam penelitian ini yaitu sebesar 2,21\% dengan kategori sehat.

Inflasi tidak berpengaruh terhadap tingkat likuiditas. Hal ini menunjukkan bahwa setiap kenaikan inflasi sebesar satu persen tidak ada penurunan atau peningkatan tingkat likuiditas. Inflasi tidak berpengaruh terhadap likuiditas karena bank syariah tidak memakai mekanisme suku bunga, sehingga tingkat bagi hasil atau margin laba produk bank syariah tidak harus menyesuaikan dengan tingkat inflasi seperti halnya tingkat suku bunga bank konvensional.

\section{Reference}

Amelia, K. C., \& Murtasih, S. (2017). Analisis Pengaruh DPK, LDR, NPL, dan CAR terhadap jumlah Penyaluran Kredit pada PT. Bank QNB Indonesia,Tbk. Jurnal Ekonomi Bisnis Vol. 22 No.1 , 56-70.

Antonio, M. S. (2010). Bank Syariah : Dari Teori ke Praktik. Jakarta: Gema Insani Persada, hlm. 95.

Arifin, Z. (2009). Dasar-Dasar Manajemen Bank Syariah. Jakarta: Azkia Publisher. hlm.179.

Basuki , A. T., \& Yuliadi, I. (2015). Ekonometrika Teori \& Aplikasi. Yogyakarta: Mitra Pustaka Nurani.

Bernardin, E. D. (2016). Pengaruh CAR dan LDR terhadap ROA. Ecodemica. Vol IV No.2, 239.

Dendawijaya, L. (2005). Manajemen Perbankan. Jakarta: Ghalia Indonesia. hlm.47.

Djauhari, T. A. (2012). Likuiditas. Jurnal Nasional , 192.

Ervina, \& Adriansyah, A. (2016). Pengaruh Dana Pihak Ketiga, Non Performing Financing, Good Corporate Goverance, Return On Asset, dan Capital Adequacy Ratio Terhadap Debt Financing (Studi Kasus Bank Umum Syariah di Indonesia). Managemen Analisys Journal Vol 5, 7-16.

Fakultas Ekonomi dan Bisnis Islam - UIN Sunan Gunung Djati Bandung 
Faturrahman, A., \& Rusdi, F. (2019). Analisis Faktor-Faktor Yang Mempengaruhi Likuiditas Bank Syariah di Indonesia Menggunakan Metode Vector Error Correction Model. Al-Masraf (Jurnal Lembaga Keuangan dan Perbankan) Volume. 4 Nomor.2, 12124.

Fikriati, N. K. (2015). (Skripsi) Analisis Pengaruh Dana Pihak Ketiga, Non Performing Financing dan Inflasi terhadap Financing to Deposit Ratio pada Bank Pembiayaan Rakyat Syariah di Indonesia. Jakarta: UIN Syarif Hidayatullah Jakarta.

Hadiyati, P. (2013). Pengaruh Non Performing Financing Pembiayaan Mudharabah dan Musyarakah Pada Bank Syariah Muamalat Indonesia. e-Jurnal Manajemen dan Bisnis, Vol.1 No. 8, 8.

Hersugondo, \& Tamtomo, H. S. (2012). Pengaruh CAR,NPL,DPK, dan ROA terhadap LDR Perbankan di Indonesia. Jurnal Dharma Ekonomi No. 36 XIX, 183.

Muhammad. (2015). Manajemen Dana Bank Syariah. Jakarta: PT RajaGrafindo Persada. hlm.157.

Murzaki. (2012). Pengaruh Rasio Keuangan Terhadap Modal Kerja Perbankan di Indonesia. Jurnal Visioner dan Strategis Vol.1, 83.

Nandadipa. (2010). Pengaruh CAR, NPL, Inflasi, Pertumbuhan DPK dan Echange Rate terhadap LDR (Studi Kasus Pada Bank Umum di Indonesia. Semarang: Universitas Diponegoro.

Novitasari. (2016). Analisis Faktor-Faktor yang Mempengaruhi Financing to Deposit Ratio (FDR) Sebagai Indikator Likuiditas Pada Perbankan Syariah di Indonesia (Periode Triwulan I 2003IV 2013). Jurnal Ilmiah Mahasiswa FEB Vol.3 No.2, 54.

Nursuhartatik, \& Kusumaningtias, R. (2019). Determinan Financing to Deposit Ratio. Jurnal Ilmu Manajemen Volume 1 Nomor 4, 1181-1182.

Prakoso, D. (2017). Determinan Financing To Deposit Ratio Bank Umum Syariah Di Indonesia Periode 2012-2015. Jurnal Ekonomi Syariah Teori dan Terapan Vol.4 No 11, 890.

Rahardja, P., \& Manurung, M. (2004). Teori Ekonomi Makro : Suatu Pengantar edisi Il. Jakarta: FE UI, hlm. 155.

Rani, L. N. (2017). Analisis Pengaruh Faktor Eksternal dan Internal Perbankan Terhadap Likuiditas Perbankan Syariah Di Indonesia Periode Januari 2003 - Oktober 2015. al-Uqud : Jurnal of Islamic Economics Volume.1 Nomor.1, 56.

Rizkiyah, T. F., Yuniawati, W., \& Wiyanti, R. I. (2018). Kualitas Aset dan Likuiditas Dalam Mempengaruhi Kinerja Keuangan PT Bank Mega Syariah TBK. Jurnal Wacana Ekonomi, Vol.18; No.01, 5 .

Saekhu. (2013). Pengaruh Inflasi Terhadap Kinerja Pembiayan Bank Syariah, Volume Pasar, Uang ANtar Bank Syariah Dan Posisi Outstanding Sertifikat Wadiah Bank Indonesia. Conomica Volume VI Edisi 1, 119.

Saekhu. (2015). Pengaruh Inflasi Terhadap Kinerja Pembiayaan Bank Syariah, Volume Pasar Uang antara Bank Syariah, Dan Posisi Outstanding Sertifikat Wadiah Bak Indonesia. Conomica, Volume VI , 104.

Somantri, Y. F., \& Sukmana, W. (2019). Analisis Faktor-Faktor yang Mempengaruhi Financing to Deposit Ratio (FDR) Pada Bank Umum Syariah di Indonesia. Berkala Akuntansi dan Keuangan Indonesia, Vol.04 Nomor 2, 66.

Syariah, B. U. (2014-2019). Laporan Keuangan Bank Umum Syariah. 
Trianti, K. (2014). Manajemen Risiko Pembiayaan Mudharabah. hlm 5-6.

Usanti, T. P. (2013). Transaksi Bank Syariah. Jakarta: PT. Bumi Aksara.

Utami, M. S., \& Muslikhati. (2019). Pengaruh Dana Pihak Ketiga (DPK), Capital Adequacy Ratio (CAR), Non Performing Financing (NPF) terhadap Likuiditas Bank Umum Syariah (BUS) Periode 2015-2017. Falah Jurnal Ekonomi Syariah Vol.4, No.1, 40-42.

Veithzal, R., \& Andria, P. V. (2007). Bank And Financial Institution Management. Jakarta: PT Raja Grafindo.

Waemustafa, W., \& Sukri, S. (2016). Systematic and Unsystematic Risk Determinan of Liquidity Risk Between Islamic an Conventional Banks. Internasional Journal of Economics and Financial,Vol.6, 1325-1326.

Walfajri, M. (2018). Likuiditas Bank Syariah Makin Longgar. Jakarta: Kontan.co.id.

Wardana, R. I., \& Widyarti, E. T. (2015). Analisis Pengaruh CAR,FDR,NPF,BOPO, DAN SIZE TERHADAP PROFITABILITAS PADA BANK UMUM SYARIAH DI INDONESIA. Journal Of Managemen. Vol.4 Nomor $4,2$. 